\title{
EFFECT OF DRY-WET ALTERNATION ON DISSOLVED OXYGEN CONCENTRATION IN CONSTRUCTED WETLAND
}

\author{
CHEN, X. Y. ${ }^{1,2,3^{*}}-$ ZHU, J. ${ }^{1,2,3}-$ TIAN, Z. F. ${ }^{1,2,3}-$ LI, T. ${ }^{4}-$ WU, Y. H. ${ }^{1,2,3}-$ CHEN, J. ${ }^{5}$ \\ ${ }^{1}$ School of Ecological and Environmental Sciences, East China Normal University, Shanghai \\ 200062, China \\ ${ }^{2}$ Hebei Provincial Academy of Ecological and Environmental Sciences, Shijiazhuang 050037, \\ China \\ ${ }^{3}$ Hebei Provincial Lab of water Environmental Sciences, Shijiazhuang 050037, China \\ ${ }^{4}$ Hebei Provincial Shijiazhuang Qiaoxi Sewage Treatment, Shijiazhuang 050031, China \\ ${ }^{5}$ Hebei Provincial Shijiazhuang City Drainage Monitoring Station, Shijiazhuang 050031, China \\ ${ }^{*}$ Corresponding author \\ e-mail:ecnuljj@163.com; phone: +86-1360-1903-991 \\ (Received 21 $1^{\text {st }}$ May 2020; accepted $17^{\text {th }}$ Sep 2020)
}

\begin{abstract}
The effect mechanism of dry-wet alternation on dissolved oxygen (DO) concentration in constructed wetlands have not been fully studied. In this paper, the experimental device of constructed wetland in constant temperature box is taken as the research object, and the effect is analyzed at different temperature systematically, changes of DO concentration with different substrates and effects of different dry-wet ratios on DO concentration. The results showed that the dissolved oxygen (DO) concentration increased with the decrease of temperature at different dry-wet alternation times (DAWT) $4 \mathrm{~h}, 8 \mathrm{~h}$ and $12 \mathrm{~h}$. At various temperatures $\left(10^{\circ} \mathrm{C}, 20^{\circ} \mathrm{C}, 30^{\circ} \mathrm{C}\right)$, the DO concentration decreased with the increase of DAWT. At the same dry-wet alternation time, DO concentration in each substrate increased with the higher dry-wet ratios. At the same time, it was found that the concentration of DO in the Biochar substrate was lower than that in the Common substrate (Macadam, Zeolite, volcanic rock). Therefore, the dry-wet alternation can increase the dissolved oxygen content of constructed wetland significantly, that is, reducing the dry-wet alternation time (speeding up the frequency) and increasing the dry-wet time ratio are beneficial to the recovery of the reoxygenation ability in constructed wetland.
\end{abstract}

Keywords: dry-wet ratio, biochar, substrate, dissolved oxygen, reoxygenation

\section{Introduction}

Dissolved oxygen (DO) concentration is the key factor affecting the purification effect of Constructed Wetland. The results show that the denitrification mechanism of wetland is mainly microbial nitrification, denitrification and anaerobic ammonia oxidation (Huang et al., 2014; Jiang et al., 2019). The amount of nitrogen removal by nitrification and denitrification can account for $60 \% \sim 86 \%$ of the total amount of nitrogen removal (Liu et al., 2003; Faulwetter et al., 2009; Jiang et al., 2019), and the main reason is that wetlands create a good nitrification and denitrification environment for microorganisms. However, the concentration of dissolved oxygen in the wetland is low because of the limitation of Wetland structure, which greatly limits the purification capacity of the wetland, resulting in the unsatisfactory decontamination effect of the wetland (Van-Ostrom et al., 1994; Wu et al., 2001).

Generally speaking, there are great differences in the requirements for the dissolved oxygen content in the process of microbial denitrification in constructed wetland, because 
nitrification is an aerobic process, denitrification and anaerobic ammonia oxidation are anaerobic processes, and all single oxygen environment is easy to cause the process of biological denitrification in wetland is not smooth. We know that the oxygen suitable for nitrification should be higher than $2 \mathrm{mg} / \mathrm{L}$, otherwise DO will be the limiting factor of the reaction, and $0.2 \mathrm{mg} / \mathrm{l}$ is considered as the minimum do requirement for nitrification; in addition, DO of denitrification should be controlled below $0.5 \mathrm{mg} / \mathrm{l}$, and denitrification above this value will be severely inhibited. Therefore, some new design processes that can improve the reoxygenation capacity of wetland have emerged, such as artificial aeration method (Li et al., 2001; Yan et al., 2007), tidal flow artificial wetland (Sun et al., 2005), wave type subsurface flow artificial wetland system design (He et al., 2004), indirect design water way design (Song et al., 2005; Wu et al., 2010; Zhang et al., 2015), pre aeration (Noorvee et al., 2007), ventilation pipe (Green et al., 1998; Lahav et al., 2001; Ouellet-Plamondon et al., 2006), blast aeration (Yan et al., 2007; Nivala et al., 2007), etc. Some results show that these reoxygenation measures can effectively improve the nitrification capacity of wetland, but the continuous oxygen increase will lead to a large increase in the concentration of nitrate nitrogen in the effluent of wetland, thus reducing the removal efficiency of total nitrogen (Jamieson et al., 2003). So, how to dynamically control and optimize the distribution of oxygen state in the wetland and promote the nitrification and denitrification is very important for the denitrification and decontamination effect of the wetland.

Alternation of drying and wetting is the most basic feature of wetland ecosystem. The alternation of soil / sediment / substrate water is closely related to the enrichment and removal of nutrients. Under the operation mode of dry and wet regulation, the change state of dry and wet alternation (water level fluctuation, anaerobic / aerobic environment alternation, etc.) can also occur in the constructed wetland. However, the mechanism of the effect of dry and wet alternation on the dissolved oxygen concentration in the constructed wetland has not been fully studied. In this paper, the experimental device of constructed wetland is taken as the research object, through the alternation of dry and wet regulation to improve the internal oxygen state of wetland, the change of dissolved oxygen concentration in different substrate types of constructed wetland under the alternation of dry and wet at different temperatures and the influence of different dry and wet ratio on the dissolved oxygen concentration are analyzed systematically, in order to provide theoretical reference for the optimal design of constructed wetland ecosystem Guide.

\section{Materials and methods}

\section{Experimental design}

The constructed wetland experimental device is mainly composed of raw water tank and substrate reactor, and the experimental device is placed in a constant temperature box for control, Water Environment Laboratory, Hebei Provincial Academy of Ecological and Environmental Sciences, China (Figure 1).

a) Device structure: the size of the experimental device is $100 \mathrm{~mm} \times 100 \mathrm{~mm} \times 500 \mathrm{~mm}$, which is divided into six groups of devices, three in each group are parallel, which are respectively completed in three thermostatic boxes. The water is supplied by the raw water tank in a unified way, each device is separately discharged, and the water in and out is controlled by the control valve. 




Figure 1. Experimental device diagram

b) Matrix: biocarbon matrix (reactor1-3, organic fiber material), size $100 \mathrm{~mm} \times 100 \mathrm{~mm} \times 50 \mathrm{~mm}$; gravel (reactor4), particle size $10-20 \mathrm{~mm}$; zeolite (reactor5), particle size 20-40 mm; volcanic rock (reactor6), particle size 20-30 mm.

c) Single structure: the biological carbon matrix adopts the "honeycomb" structure, i.e. the three-dimensional network structure, which is composed of straw and coconut fiber matrix, and is placed in unit 1-3 in three types respectively; gravel, zeolite and volcanic rock are placed in unit 4-6, respectively.

d) Water distribution mode: the raw water in the water tank enters the reactor from the bottom through the control of the inlet water level valve, and the outlet water level is controlled by the outlet valve.

e) Raw water: the raw water comes from the tail water of a sewage treatment plant in Shijiazhuang, Hebei Province, China. The tail water is regularly transported back to the laboratory through a transport vehicle in a bucket for standby.

f) Dry and wet alternation time (DAWT): $4 \mathrm{~h}, 8 \mathrm{~h}$ and $12 \mathrm{~h}$, respectively.

\section{Operation}

1) Table 1 shows the dry and wet alternative operation mode.

Table 1. Operation mode

\begin{tabular}{|c|c|c|c|}
\hline No. & DAWT & Inlet/outlet mode & Control condition \\
\hline 1 & $4 h$ & $\begin{array}{l}\text { The dry/wet interval is } 4 \mathrm{~h} \text {, i.e. the first hour is full of } \\
\text { water, the fourth hour is } 1 / 2 \mathrm{~V} \text {, the eighth hour is } 1 / \\
2 \mathrm{~V} \text {, the } 12 \text { th hour is } 1 / 2 \mathrm{~V} \text {, the } 16 \text { th hour is } 1 / 2 \mathrm{~V}, \ldots\end{array}$ & \multirow{3}{*}{$\begin{array}{l}\text { The samples were collected and } \\
\text { analyzed at } 10^{\circ} \mathrm{C}, 20^{\circ} \mathrm{C}, 30^{\circ} \mathrm{C} \text {, and } \\
\text { 20days after stable operation }\end{array}$} \\
\hline 2 & $8 \mathrm{~h}$ & $\begin{array}{c}\text { The dry/wet interval is } 8 \mathrm{~h} \text {, i.e. the first hour is full of } \\
\text { water, the eighth hour is } 1 / 2 \mathrm{~V} \text {, the } 16 \text { th hour is } 1 / 2 \mathrm{~V} \text {, } \\
\text { the } 24 \text { th hour is } 1 / 2 \mathrm{~V} \text {, the } 32 \text { th hour is } 1 / 2 \mathrm{~V}, \ldots\end{array}$ & \\
\hline 3 & $12 \mathrm{~h}$ & $\begin{array}{l}\text { The dry/wet interval is } 12 \mathrm{~h} \text {, i.e. the first hour is full } \\
\text { of water, the } 12 \text { th hour is } 1 / 2 \mathrm{~V} \text {, the } 24 \text { th hour is } 1 / \\
2 \mathrm{~V} \text {, the } 36 \text { th hour is } 1 / 2 \mathrm{~V} \text {, the } 48 \text { th hour is } 1 / 2 \mathrm{~V}, \ldots\end{array}$ & \\
\hline
\end{tabular}

2) Table 2 shows the Operation mode of different operation cycle (dry wet ratio). 
Table 2. Dry wet ratio operation mode

\begin{tabular}{|c|c|c|c|}
\hline No. & DAWT & inlet/outlet mode & Control condition \\
\hline 1 & $4 \mathrm{~h}$ & $\begin{array}{l}\text { The ratio of dry / wet time is } 1 \mathrm{~h}: 3 \mathrm{~h} \text {, i.e. the control water volume is } \\
1 / 2 \mathrm{~V} \text { from } 0 \text { to } 1 \mathrm{~h} \text {, then the instantaneous water inflow is } 1 / 2 \mathrm{~V} \text {, the } \\
\text { instantaneous water outflow is } 1 / 2 \mathrm{~V} \text { from full water level to } 4 \mathrm{~h} \text {, the } \\
\text { instantaneous water inflow is } 1 / 2 \mathrm{~V} \text { from } 1 / 2 \mathrm{~V} \text { to } 5 \mathrm{~h} \text {, and the } \\
\text { instantaneous water outflow is } 1 / 2 \mathrm{~V} \text { from full water level to } 8 \mathrm{~h}, \ldots\end{array}$ & \multirow{3}{*}{$\begin{array}{l}\text { The samples were } \\
\text { collected and analyzed } \\
\text { at } 10^{\circ} \mathrm{C}, 20^{\circ} \mathrm{C}, \\
30^{\circ} \mathrm{C} \text {, and } 20 \text { days after } \\
\text { stable operation }\end{array}$} \\
\hline 2 & $8 \mathrm{~h}$ & $\begin{array}{l}\text { The ratio of dry / wet time is } 2 \mathrm{~h}: 6 \mathrm{~h} \text {, i.e. the control water volume is } \\
1 / 2 \mathrm{~V} \text { from } 0 \text { to } 2 \mathrm{~h} \text {, then the instantaneous water inflow is } 1 / 2 \mathrm{~V} \text {, the } \\
\text { instantaneous water outflow is } 1 / 2 \mathrm{~V} \text { from full water level to } 8 \mathrm{~h} \text {, the } \\
\text { instantaneous water inflow is } 1 / 2 \mathrm{~V} \text { from } 1 / 2 \mathrm{~V} \text { to } 10 \mathrm{~h} \text {, and the } \\
\text { instantaneous water outflow is } 1 / 2 \mathrm{~V} \text { from full water level to } 16 \mathrm{~h}, \ldots\end{array}$ & \\
\hline 3 & $12 \mathrm{~h}$ & $\begin{array}{l}\text { The ratio of dry / wet time is } 4 \mathrm{~h}: 8 \mathrm{~h} \text {, i.e. the control water volume is } \\
1 / 2 \mathrm{~V} \text { from } 0 \text { to } 4 \mathrm{~h} \text {, then the instantaneous water inflow is } 1 / 2 \mathrm{~V} \text {, the } \\
\text { instantaneous water outflow is } 1 / 2 \mathrm{~V} \text { from full water level to } 12 \mathrm{~h} \text {, the } \\
\text { instantaneous water inflow is } 1 / 2 \mathrm{~V} \text { from } 1 / 2 \mathrm{~V} \text { to } 16 \mathrm{~h} \text {, and the } \\
\text { instantaneous water outflow is } 1 / 2 \mathrm{~V} \text { from full water level to } 24 \mathrm{~h}, \ldots\end{array}$ & \\
\hline
\end{tabular}

\section{Analysis index and methods}

1) Do is determined by thermo Orion five star portable tester (Thermo Fisher Scientific Inc., American), $\mathrm{NH}_{3}-\mathrm{N}, \mathrm{NO}_{3}-\mathrm{N}, \mathrm{NO}_{2}-\mathrm{N}, \mathrm{TN}$ and other chemical indexes are determined according to the national standard method (State Environmental Protection Agency).

2) Sampling time: The experiment was carried out in July-October 2019. The samples were collected at $10^{\circ} \mathrm{C}, 20^{\circ} \mathrm{C}$ and $30^{\circ} \mathrm{C}$ for 20 days, and three samples were collected for each time.

3) The results were statistically processed using one-way ANOVA, assuming the significance level of $\alpha=0.05$, with Origin version8.0. The Spearman correlation analysis was carried out by using the SPSS20.0.

4) Water quality sampling: Sampling ports were set at $40 \mathrm{~cm}$ in the lower layer of the reactor in the routine experiment; and at $10 \mathrm{~cm}$ in the upper layer, $15 \mathrm{~cm}$ in the middle layer and $40 \mathrm{~cm}$ in the lower layer of the reactor in the vertical experiment.

5) DO Sampling: The probe of portable detector was placed at $40 \mathrm{~cm}$ in the lower layer of the reactor in the conventional experiment; and, the probe was placed at $10 \mathrm{~cm}$ in the upper layer, $15 \mathrm{~cm}$ in the middle layer and $40 \mathrm{~cm}$ in the lower layer of the reactor in the vertical experiment.

\section{Result}

\section{DO concentration change}

Change of dissolved oxygen with temperature at different dry / wet intervals

It can be seen from Figure 2 that in the constructed wetland experimental device, the DO concentration value in each substrate increases with the decrease of temperature (DO change value $<3 \mathrm{mg} / \mathrm{L}$ ) at $4 \mathrm{~h}$ and $12 \mathrm{~h}$ of DAWT, while the DO concentration value in each substrate does not change significantly with the change of temperature at $8 \mathrm{~h}$ of DAWT. At the same time, the DO concentration in biochar matrix $(1,2,3)$ is lower than that in common matrix (gravel, zeolite, volcanic rock) (DO change value $<3 \mathrm{mg} / \mathrm{L}$ ). At 
this time, under the dry and wet alternate condition, reducing the time of dry wet alternation (i.e. accelerating the frequency) is conducive to the improvement of wetland reoxygenation capacity (DO change value $<3 \mathrm{mg} / \mathrm{L}$ ).


Figure 2. Change of dissolved oxygen with temperature (*, $a=0.05 ; n=9)$

\section{Change of dissolved oxygen with dry/wet interval time at different temperatures}

It can be seen from Figure 3 that at low temperature of $10^{\circ} \mathrm{C}$, the concentration of DO in each matrix does not change significantly at $4 \mathrm{~h}$ and $12 \mathrm{~h}$ of DAWT, but decreases at $8 \mathrm{~h}$ of DAWT (DO change value $<3 \mathrm{mg} / \mathrm{L}$ ); At $20^{\circ} \mathrm{C}$, the concentration of DO in each matrix does not change significantly with the time of DAWT; At $30^{\circ} \mathrm{C}$, the concentration of DO in each matrix does not change significantly. The concentration of oxygen (DO) decreased with the increase of DAWT time (DO change $<3 \mathrm{mg} / \mathrm{L}$ ). At the same time, DO concentration in biochar matrix $(1,2,3)$ is lower than that in common matrix (gravel, zeolite, volcanic rock). It is also found that reducing the dry wet alternate time (fast increase frequency) is conducive to the improvement of wetland reoxygenation capacity (DO change value $<3 \mathrm{mg} / \mathrm{L}$ ) under low temperature.

\section{Change of dissolved oxygen in profile}

It can be seen from Figure 4 that at low temperature of $10^{\circ} \mathrm{C}$, the concentration of DO in the bottom of each matrix is less than the upper value, that is, DO decreases with the increase of depth (DO change value $<1.5 \mathrm{mg} / \mathrm{L}$ ).

\section{Change of dissolved oxygen under different dry wet ratio}

In order to study and analyze the change of dissolved oxygen under different operation cycles (dry to wet ratio, D/W ratio), only biochar matrix is selected for comparative analysis. 



Figure 3. Change of dissolved oxygen with dry wet alternation time $(*, a=0.05 ; n=9)$
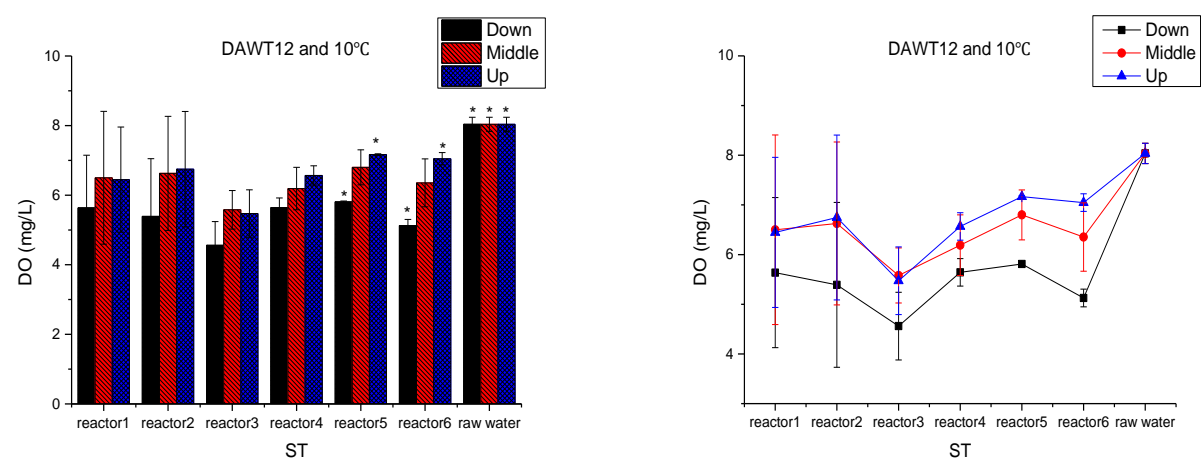

Figure 4. Change of dissolved oxygen in profile ( $\left.{ }^{*}, a=0.05 ; n=9\right)$

It can be seen from Figure 5 that the concentration value of DO in the substrate does not change significantly (DO change value is less than $1.5 \mathrm{mg} / \mathrm{L}$ ) compared with the concentration value in the original water at the dry wet alternation (DAWT) $4 \mathrm{~h}$ (dry wet ratio 1 h:3 h, 2 h:2 h, 3 h:3 h), 8 h (dry wet ratio 2 h:6 h, 4 h: 4 h, 6 h:2 h), 12 h (dry wet ratio $4 \mathrm{~h}: 8 \mathrm{~h}, 4 \mathrm{~h}: 6 \mathrm{~h}, 8 \mathrm{~h}: 4 \mathrm{~h}$ ).

When the temperature is $30^{\circ} \mathrm{C}$, the DO concentration in the substrate decreases first and then increases with the time of DAWT; At $20^{\circ} \mathrm{C}$, the DO concentration in the substrate increased first and then decreased with the time of DAWT; At the temperature of $10^{\circ} \mathrm{C}$, the DO concentration in the substrate decreased with the increase of DAWT. At all of the temperature, the DO concentration in the substrate with the dry wet ratio of $3 \mathrm{~h}: 1 \mathrm{~h}$ is higher than that in the other substrate. At the same time, it is found that the DO concentration in the biochar matrix increased with the increase of the ratio of dry to wet 
(do change value $<1.5 \mathrm{mg} / \mathrm{L}$ ). It is also found that under the low temperature condition, reducing the alternate time of dry to wet (fast increase frequency) and increasing the ratio of dry to wet time arw beneficial to the improvement of the wetland's reoxygenation capacity (DO change value $1.5 \mathrm{mg} / \mathrm{L}$ ).
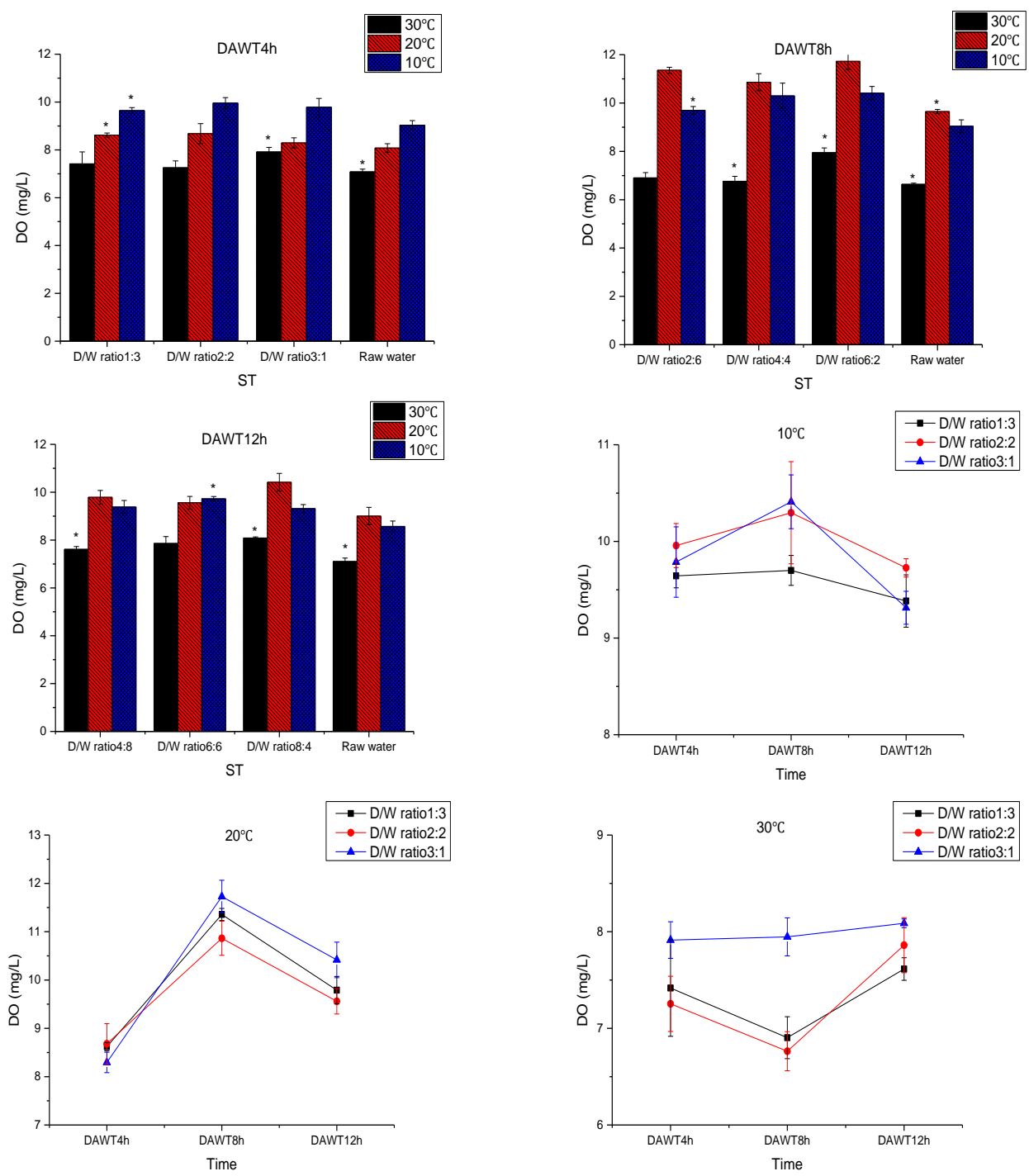

Figure 5. Change of dissolved oxygen under different dry wet ratio $(*, a=0.05 ; n=9)$

\section{The relationship between dry wet alternation time and $\mathrm{DO}$ response}

It can be seen from Table 3 that under the influence of alternation of dry and wet in constructed wetland, DO in each substrate is significantly correlated with the interval of dry and wet for $12 \mathrm{~h}$ (Pearson correlation, $\mathrm{P}<0.01$ ), and DO in biocarbon matrix 2, gravel, zeolite and volcanic rock matrix is significantly correlated with the interval of dry and wet for $4 \mathrm{~h}$ (Pearson correlation, $\mathrm{P}<0.05$ ), but not in other cases. And DO in crushed stone matrix is significantly correlated with temperature of $30^{\circ} \mathrm{C}$ (Pearson correlation, $\mathrm{P}<0.05$ ), but not in other cases. 
Table 3. The relationship between DAWT and DO response

\begin{tabular}{|c|c|c|c|c|c|c|c|}
\hline \multirow{2}{*}{\multicolumn{2}{|c|}{ Dry and wet conditions }} & \multicolumn{6}{|c|}{ Matrix type } \\
\hline & & Biochar1 & Biochar2 & Biochar3 & Gravel & zeolite & volcanic rock \\
\hline \multirow{3}{*}{ DAWT } & $4 \mathrm{~h}$ & -0.578 & $-0.753 *$ & -0.624 & $-0.667 *$ & $-0.741 *$ & $-0.794 *$ \\
\hline & $8 \mathrm{~h}$ & 0.111 & -0.006 & 0.054 & -0.178 & 0.067 & 0.088 \\
\hline & $12 \mathrm{~h}$ & $-0.908 * *$ & $-0.794 *$ & $-0.814^{*}$ & $-0.923 * *$ & $-0.760 *$ & $-0.701 *$ \\
\hline \multirow{3}{*}{ Temperature } & $30^{\circ} \mathrm{C}$ & -0.525 & -0.381 & -0.456 & $-0.677 *$ & -0.479 & -0.097 \\
\hline & $20^{\circ} \mathrm{C}$ & 0.085 & 0.029 & 0.126 & 0.326 & 0.331 & 0.486 \\
\hline & $10^{\circ} \mathrm{C}$ & -0.020 & -0.041 & -0.164 & 0.213 & 0.150 & 0.223 \\
\hline
\end{tabular}

Note: $\mathrm{n}=9 ; *$, significant correlation at 0.05 level (bilateral); **, significant correlation at 0.01 level (bilateral)

\section{Discussion}

Generally, in natural wetlands, through the natural vegetation, substrate and water level fluctuations and other factors, can achieve the aerobic environment, anaerobic environment and facultative environment alternately, that is, it provides the conditions for the survival of aerobic and ANAEROBIC microflora in wetland, and is beneficial to the removal of pollutants (Faulwetter et al., 2009; Jiang et al., 2019). The dissolved oxygen (DO) content in constructed wetland can be changed by Water / Hydrology Regulation, which makes it appear dry-wet alternate (Anaerobic / Aerobic Environment Alternate). Therefore, wet-dry alternation is an effective method to realize aerobic and anaerobic environment in constructed wetland.

The concentration of dissolved oxygen in wetland is low, which greatly limits the purification space of wetland and leads to the unsatisfactory decontamination effect because of the limitation of wetland structure (Van-Oostrom and Russell, 1994; Wu and Franz, 2001). It has been studied that the reaeration efficiency and the wetland treatment effect can be improved when the dry-wet ratio is 1:2 (8 h:12 h) (Shi et al., 2015). We find that the dry-wet alternate operation mode adopted in this paper can effectively increase the dissolved oxygen (DO) content in the wetland, and the DO concentration in the substrate at the dry-wet ratio of 3:1 $(3 \mathrm{~h}: 1 \mathrm{~h} / 6 \mathrm{~h}: 2 \mathrm{~h})$ is higher than that at other dry-wet ratios. The reason is that increasing the dry-wet time ratio, that is, increasing the time of the substrate exposed to the air, so that more oxygen in the air into the wetland substrate. Therefore, wet-dry alternation is an effective method to realize the reoxygenation of constructed wetland.

It was found that the dissolved oxygen content was the main factor affecting the removal rate of pollutants in constructed wetlands (Maltais-Landry et al., 2009), because oxygen content directly affected the biochemical pathways of pollutants in different reduction states (Liu et al., 2017). It is reported that the oxygen output of plants is only1 8 $\mathrm{g} /\left(\mathrm{m}^{2} \mathrm{~g}\right)$, and the lack of oxygen supply becomes the speed-limiting step of pollutant removal (Zheng et al., 2011). The dry-wet alternate operation mode adopted in this paper is an important technology to effectively improve the removal efficiency of organic matter in constructed wetland (Ding et al., 2015). The results showed that the DO concentration decreased with the increase of dry-wet alternate time (DAWT), that is to say, reducing the dry-wet alternate time could increase the DO content in constructed wetland and promote the removal of pollutants (Zhao et al., 2011). 
Through the significance analysis (Table 3), it is found that the alternation of dry and wet can significantly affect and improve the content of DO in the wetland matrix, and can realize the artificial aerobic, and create an aerobic environment for the wetland system microorganisms (Liu et al., 2017; Huang, 2018; Kang et al., 2019). In this study, it is found that temperature has no obvious effect on DO content.

\section{Conclusions}

(1) It can be concluded from the study of the incubator constructed wetland experimental device that DO concentration in all substrates increases with the decrease of temperature in different DAWT at $4 \mathrm{~h}, 8 \mathrm{~h}$ and $12 \mathrm{~h}$, and decreases with the increase of DAWT at $10^{\circ} \mathrm{C}, 20^{\circ} \mathrm{C}$ and $30^{\circ} \mathrm{C}$ in different temperature. The concentration of DO in biochar matrix $(1,2,3)$ is lower than that in common matrix (gravel, zeolite, volcanic rock). At this time, under the dry and wet alternate condition, reducing the time of dry wet alternation (i.e. accelerating the frequency) is conducive to the improvement of wetland reoxygenation capacity.

(2) It was found that the concentration of DO in biomass matrix did not change significantly in 4 hours ( 1 h:3 h, 2 h:2 h, 3 h:3 h), 8 hours ( 2 h:6 h, 4 h:4 h, 6 h:2 h), 12 hours $(4 \mathrm{~h}: 8 \mathrm{~h}, 4 \mathrm{~h}: 6 \mathrm{~h}, 8 \mathrm{~h}: 4 \mathrm{~h})$ of DAWT. At different temperatures of $30^{\circ} \mathrm{C}, 20^{\circ} \mathrm{C}$ and $10^{\circ} \mathrm{C}$, the DO concentration in the matrix increased with the increase of the ratio of dry to wet time. In addition, the DO concentration in the substrate with the dry wet ratio of 3 $\mathrm{h}: 1 \mathrm{~h}$ is higher than that in the other substrate. It is also concluded that reducing the frequency of dry wet alternation and increasing the ratio of dry wet time are conducive to the improvement of wetland reoxygenation capacity at dry and wet alternate condition (DO change value $<1.5 \mathrm{mg} / \mathrm{L}$ ).

(3) In the study of constructed wetland profile at low temperature of $10^{\circ} \mathrm{C}$, it was found that the concentration of DO in the bottom of each substrate was lower than that in the upper part, that is, the do value decreased with the increase of depth.

(4) It is found that the alternation of dry and wet can significantly affect and improve the content of DO in the wetland matrix, and can realize the artificial aerobic, and create an aerobic environment for the wetland system microorganism. It is also found that temperature has no obvious effect on DO content.

(5) What is the dynamic change of dry-wet time ratio and DO concentration under the condition of dry-wet alternation? And how to optimize the design of pollutants removal effect? And other issues need to be further studied.

Acknowledgements. This work was supported by the Major Science and Technology Program for Water Pollution Control and Treatment [grant number 2018ZX07110-006].

\section{REFERENCES}

[1] Ding, Y., Wang, W., Wang, Y. H., Song, X. S. (2015): Research on the mechanism of nitrogen removal and its main influencing factors in horizontal subsurface flow constructed wetlands. - Industrial Water Treatment 5(6): 6-9.

[2] Faulwetter, J. L., Gagnon, V., Sundberg, C., Chazarenc, F., Mark, D. B., Brisson, J., Anne, K. C., Otto, R. S. (2009): Microbial processes influencing performance of treatment wetlands: a review. - Ecological Engineering 35(6): 987-1004. 
[3] Green, M., Friedler, E., Safrai, I. (1998): Enhancing nitrification in vertical low constructed wetland utilizing a passive air pump. - Water Research 32(12): 3513-3520.

[4] He, C. D., Tan, L., Ge, L. Y., Ji, J. J., Ye, Y. L., He, L., Wang, H. M. (2004): Application of Wavy Subsurface Constructed Wetland in Treating Domestic Sewage. - Journal of Agro-Environment Science 23(4): 766-769.

[5] Huang, J., Yang, S. S., Li, R. Q., Fu, D. F. (2014): Nitrification intensity and ammoniaoxidizing microorganisms in wetland plant rhizosphere soil at low temperature. - Research of Environmental Sciences 27(8): 857-864.

[6] Huang, J. (2018): Research on Transformation of Endogenous Nitrogen and Mechanism of Microorganism by Intermittent Aeration in Polluted River. - An Hui University.

[7] Jamieson, T. S., Stratton, G. W., Gordon, R., Madani, A. (2003): The use of aeration to enhance ammonia nitrogen removal in constructed wetlands. - Canadian Biosystems Engineering 45: 109-114.

[8] Jiang, X. Y., Ji, X. Y., Huang, D. Y., Zhang, J. B. (2019): Microbial community structure in the roots of three kinds of plants in integrated vertical flow constructed wetlands. Journal of Agro-Environment Science 38(1): 176-183.

[9] Kang, X. R., Liu, Y. L., Zhou, Y. X., Su, Y. (2019): Studies on Intermittent Aeration Enhancing Nitrogen Removal of Constructed Wetland at Low Temperature. - Forest Engineering 35(3): 74-78.

[10] Lahav, O., Artzi, E., Tarre, S., Green, M. (2001): Ammonium removal using a novel unsaturated flow biological filter with passive aeration. - Water Research 35(2): 397-404.

[11] Li, S., Wang, W. D., Qiang, Z. M., Zhang, M. X., Liang, X. Q., Wang, F. E., Chen, Y. X. (2001): Denitrification of rural domestic wastewater with self-aeration constructed wetland. - Environmental Science \& Technology 34(3): 19-22.

[12] Liu, C. X., Dong, C. H., Li, F. G., Hu, H. Y., Huang, X., Shi, H. C., Qian, Y. (2003): Study on Ability of Nitrification in a Subsurface Constructed Wetland System Treating Sewage. - Environmental Sciences 24(1): 80-83.

[13] Liu, Y. J., Han, X., Liu, H., Wang, Z. (2017): Effects of Aeration Patterns on Nitrogen Removal in Constructed Wetlands. - Shangdong Chemical Industry 46(5): 152-155.

[14] Maltais-Landry, G., Maranger, R., Brisson, J., Chazarenc, F. (2009): Nitrogen transformations and retention in planted and artificially aerated constructed wetlands. Water Research 43(2): 535-545.

[15] Nivala, J., Hoos, M. B., Cross, C., Wallace, S., Parkin, G. (2007): Treatment of landfill leachate using an aerated, horizontal subsurface-flow constructed wetland. - Science of Total Environment 380(1-3): 19-27.

[16] Noorvee, A., Pōldvere, E., Ülo, M. (2007): The effect of pre-aeration on the purification processes in the long-term performance of a horizontal subsurface flow constructed wetland. - Science of Total Environment 380: 229-236.

[17] Ouellet-Plamondon, C., Chazarenc, F., Comeau, Y., Brisson, J. (2006): Artificial aeration to increase pollutant removal efficiency of constructed wetlands in cold climate. Ecological Engineering 27(3): 258-264.

[18] Song, T. H., Yin, J., Cui, Y. B. (2005): Comparison and Analysis of the Different Inflows and Effluent Ways of Constructed Wetland for the Removal Rate of Wastewater. - Safety and Environmental Engineering 12: 46-49.

[19] State Environmental Protection Agency (2002): Method for determination and analysis of water and wastewater (Fourth Edition). - Beijing: China Environmental Science Press, pp. 200-284.

[20] Sun, G., Zhao, Y., Allen, S. (2005): Enhanced removal of organic matter and ammoniacalnitrogen in a column experiment of tidal flow constructed wetland system. - Journal of Biotechnology 115(2): 189-97.

[21] Van-Ostrom, A. J., Russell, J. M. (1994): Denitrification in constructed wastewater wetlands receiving high concentration of nitrate. - Water Science Technology 29: 7-14. 
[22] Wu, M. Y., Franz, E. H. (2001): Chen S. Oxygen fluxes and ammonia removal efficiencies in constructed treatment wetlands. - Water Environmental Research 73(6): 661-666.

[23] Wu, S. B., Zhang, D. X., Liu, Q. Q., Zhai, X., Hu, J., Dong, R. J. (2010): Performance optimization of a lab-scale tidal flow constructed wetland for domestic wastewater treatment. - Journal of China Agricultural University 15(2): 106-113.

[24] Yan, L., Wang, S. H., Zhong, Q. S., Huang, J., Liu, Y., Wang, F. (2007): Study on Running Characteristics of Aerating Subsurface Flow Wetlands. - Environmental Sciences 28(4): 736-741.

[25] Zhang, Y. Q., Cui, L. J., Li, W., Li, K. (2015): Study on the Intensity of Matrix Nitrification and Denitrification in Tidal Flow Contructed Wetlands. - Ecology and Environmental Sciences 3: 480-486.

[26] Zhao, Y., Li, F. G., Wang, H. Y., Li, Y., Zhang, M. Q., Wang, Z. Y. (2011): The relationship between microbial diversity and water purification capacity in aerobic/anaerobic subsurface flow constructed wetland. - Acta Scientiae Circumstantiae 31(11): 2421-2431.

[27] Zheng, T. T., Ji, J. J., Ji, R. P., Chen, J. (2011): Progress of Nitrogen Removal in Constructed Wetlands. - Environmental Science and Technology 24(S1): 111-115. 